\title{
APLIKASI ANDROID SEBAGAI MEDIA ALTERNATIF PROMOSI PRODUK DAN TRAINING DI PT DJARUM BERBASIS AUGMENTED REALITY
}

\author{
Andi Santoso \\ Fakultas Teknik, Program Studi Teknik Informatika \\ Universitas Muria Kudus \\ Email: andiansa7488@gmail.com \\ Tri Listyorini \\ Fakultas Teknik, Program Studi Teknik Informatika \\ Universitas Muria Kudus \\ Email: trilistyorini.ti.umk@gmail.com \\ Arief Susanto \\ Fakultas Teknik, Program Studi Teknik Informatika \\ Universitas Muria Kudus \\ Email: ariefpj1@gmail.com@gmail.com
}

\begin{abstract}
ABSTRAK
Augmented Reality merupakan suatu lingkungan yang memasukkan Object 3D kedalam dunia nyata secara real time. Dalam Penelitian ini, akan menerapkan tegnology AR kedalam katalog Produk PT Djarum, Sehingga katalog Produk Djarum ini bisa menjadi real dengan adanya Object 3D Produk rokok. Aplikasi ini merupakan aplikasi yang berjalan pada platform Android dan dibangun pada program Unity. Dimana aplikasi ini adalah video streaming yang diambil dari kamera smartphone Android sebagai pendeteksi sumber masukan, kemudian aplikasi ini akan mendeteksi dan melacak marker tiap produk yang telah dikonfigurasi dan diintegrasikan pada link resmi vuforia dengan menggunakan system tracking, sehingga model 3D Object produk Djarum seolah-olah akan muncul pada maeker tersebut. Dengan adanya aplikasi ini, diharapkan akan menambah gairah para pelaku training diperusahaan terkait untuk selalu belajar mengenai produk Cjarum tersebut, dan sebagai media alternatif yang menarik untuk pemasaran produk PT Djarum tersebut.
\end{abstract}

Kata kunci: 3D, android, Augmented Reality, pt djarum, unity vuforia.

\begin{abstract}
Augmented Reality is an environment that includes a $3 D$ object in the real world in real time. In this study, will implement a product Catalog into the AR tegnology PT Djarum, product Catalogs Djarum So this could be real with $3 D$ Object cigarette products. This application is an application that runs on the Android platform and built in Unity program. Where this application is a video stream captured from camera Android smartphone as a detector input source, then this application will detect and track marker each product that has been configured and integrated into the official link vuforia by using the system of tracking, so the 3D model Object products Djarum as if will appear on the maeker. With this application, is expected to add to the excitement of the actors in the company training related to always learn about the Cjarum products, and as an attractive alternative media for marketing the products of PT Djarum
\end{abstract}

Keywords: 3D, android, Augmented Reality, pt djarum, unity vuforia.

\section{PENDAHULUAN}

Rokok merupakan salah satu kebutuhan manusia yang tentunya penggemar rokok, banyak dari para penggunanya adalah kaum laki-laki, dari rata rata orang didunia ini lebih dari $30 \%$ adalah perokok sehingga kebutuhan rokok perharinyapun sangat tinggi dan terjadi kenaikan setiap tahunnya. Augmented Reality merupakan suatu lingkungan yang memasukkan Object 3D kedalam dunia nyata dalam waktu yang bersamaan. AR mengijinkan penggunanya untuk berinteraksi secara real [1].

Pada penelitian penerapan Augmented Reality pada aplikasis katalog rumah membahas tentang Augmented Reality (AR) adalah suatu lingkungan yang memasukkan objek virtual 3D kedalam lingkungan nyata secara real-time. Penelitian ini akan memasukkan teknologi AR kedalam katalog 
penjualan rumah pada Perumahan Muna Permai, sehingga katalog rumah ini menjadi lebih real dengan adanya objek 3D pada rumah. Aplikasi ini merupakan aplikasi yang berjalan pada platform mobile android, dimana aplikasi AR ini memerlukan video streaming yang diambil dari kamera smartphone sebagai sumber masukan, kemudian aplikasi ini akan melacak dan mendeteksi marker (penanda) dengan menggunakan sistem tracking, setelah marker terdeteksi, model rumah 3D pada katalog akan muncul diatas marker seolah-olah model rumah tersebut nyata. Dengan adanya aplikasi ini diharapkan akan terjadi peningkatan minat pembeli terhadap rumah yang ditawarkan oleh pengelola Perumahan Muna Permai Kudus [2].

Penerapan Augmented Reality ini juga diterapkan pada penelitian 3D Catalog Mountain View Residence berbasis Augmented Reality. Go green merupakan upaya penghijauan bumi yang saat ini sudah mengalami Global Warming. Hal ini yang banyak dilakukan oleh semua pihak, untuk mengurangi pemanasan global. Go green ini juga dilakukan pada developer hunian Mountain View Residence. Dalam memasarkan hunian masih menggunakan katalog dan selebaran berupa kertas. Dengan berkembangnya metode Augmented Reality, hal ini diharapkan dapat mengurangi penggunaan katalog kertas yang sering digunakan. Augmented Reality merupakan penggabungan benda-benda nyata dan maya di lingkungan nyata, berjalan secara interaktif dalam waktu nyata, dan terdapat integrasi antarbenda dalam tiga dimensi, yaitu benda maya terintegrasi dalam dunia nyata. Tujuan dari 3D-Catalog ini agar dapat digunakan oleh semua orang yang berminat pada hunian tersebut. Dengan 3D-Catalog diharapkan konsumen lebih tertarik, karena langsung menampilkan denah hunian secara 3 dimensi.Data yang diambil merupakan denah-denah yang dipasarkan pada hunian Mountain View Residence.3D-Catalog ini dapat dipergunakan dengan fasilitas marker yang dapat diperlihatkan secara visual maupun cetak. Metode yang dipergunakan dalam 3D-Catalog menggunakan Markeless Augmented Reality. Dengan metode ini konsumen tidak perlu lagi menggunakan sebuah marker untuk menampilkan elemen-elemen digital. Diharapkan dengan 3D-Catalog ini dapat meningkatkan minat konsumen terhadap hunian tersebut [3].

Pengguna AR semakin berkemabang dimasa ini, dan diperkirakan akan melebar dan berkembang secara sigifikan. Hal ini dikarenakan bahwa AR sangat mudah digunakan dan menarik untuk diterapkan pada suatu hal-hal yang membutuhkan gambaran imajinasi dalam bentuk 3D [4]. Seperti contoh, Pemasaran produk PT Djarum terhadap para konsumenya.

Perusahaan Rokok di Indonesia sangatlah berperan penting dalam perkembangan dan kenaikan devisa negara, Banyak perusahaan besar yang memproduksi rokok dengan kualitas dan gaya desaign yang berbeda-beda, beberapa contohnya adalah PT Djarum, Pt Gudang Garam, Sampoerna, dan banyak lagi yang lainnya. Hal ini yang menjadikan persaingan ketat para pelaku perusahaan roko tersebut untuk menampilkan hasil dan desain serta kualitas yang terbaik pada setiap produk yang mereka pasarkan, sehingga sangat dibutuhkan hal baru yang menarik dan menggugah gairah para pengguna rokok untuk senantiasa setia pada produk rokok tersebut.

Di PT Djarum misalnya, dengan menggunakan tegnology AR maka untuk promosi yang akan dijalankan akan lebih menarik karena konsumen akan melihat Object 3D Produk PT Djarum tersebut secara langsung pada smartphone mereka sehingga rasa penasaran dan keinginan untuk mecobanya lebih tinggi, selain itu juga dengan memanfaatkan apliksi AR tersebut, pada bagian training sangat besar manfaatnya yaitu seorang tariner akan lebih mudah dalam menerangkan detail dari produk Djarum tersebut dengan mengguna tampilan Object 3D tidak secra 2D lagi selain itu juga gairah para karyawan baru akan semakin tinggi untuk mempelajari produk yang kelak mereka buat ketika terjun pada lapangan produksi rokok tersebut [5]. Dalam Aplikasi AR ini para penggunanya akan dapat melihat secara detail bentuk dari pack dan rokok yang ada dalam satu brand produk, dengan dilengkapi informasi yang cukup mengenai spesifikasi dari pack maupun rokok yang ditampilkan aplikasi AR dalam bentuk 3D tersebut. Sehingga hal ini merupakan gebrakan yang sangat inovatif dalam dunia pemasaran maupun training unit untuk para pengguna rokok.

\section{METODOLOGI}

Metode atau tahapan pada perancangan aplikasi ini, menggunkan Prototype Model. Dimana sistem ini nantinya akan dapat dikembangkan lebih baik lagi.Tahapan Prototype model meliputi Listen to Customer, Build/Revise, Customer Test Drives Mock-Up [6]. Tahapan tersebut akan dijelaskan sebagai berikut:

\subsection{Listen To Customer}

Listen To Customer (Mendengarkan Pelanggan) merupakan tahap awal dari Prototype Model dimana Developer dan Customer akan bertemu, dalam hal ini Developer adalah pihak yang membangun 
aplikasi sedangkan Customer/Client adalah perusaaan yang nantinya akan menggunakan aplikasi tersebut. Developer dan Customer berrtemu untuk merencanakan tujuan, kebutuhan, dan pengumpulan data yang dibutuhkan. Untuk mendapatkan data -data yang lengkap dan akurat, diperlukan kerja sama yang baik antara kedua belah pihak. Adapun langkah-langkah yang dilakukan untuk melakukan pengumpulan data adalah sebagai berikut:

1. Sumber Data Premier

Metode pengumpulan data yang digunakan pada Penelitian ini adalah sebagi berikut:

a. Observasi

Teknik pengumpulan data yang dilakukan dengan cara meninjau langsung pada instansi terkait yaitu di PT Djarum untuk melihat produk-produk yang akan dirancang pada komputer dan menentukan maker yang tepat untuk tiap produknya.

b. Interview

Teknik pengumpulan data yang dilakukan dengan cara melakukan interview/wawancara secara langsung pada bagian pimpinan produksi PT Djarum yang mengelola bagian produksi, marketing dan training unit.

2. Sumber data Sekunder

a. Studi Literatur

Metode pengumpulan data dengan cara mengumpulkan literatur, dokumen, dan bacaanbacaan untuk mendapatkan gambaran yang menyeluruh penelitian yang akan dilakukan.

b. Studi Kepustakaan

Metode pengumpulan data dari buku-buku yang sesuai dengan permasalahn yang terjadimisalnya buku Augmented Reality, Android, dan Object 3D.

\subsection{Build/Rivese}

Build/Rivese (Perancangan Sample), perancangan yang dilakukan dengan cepat dan telah mewakili semua aspek perangkat lunak yang diketahui dan rancangan ini menjadi dasar dari pembuatan Prototype. Setelah mengetahui kebutuhan pelanggan pada tahapan listen to Customer tentang tujuan yang diharapkan maka langkah selanjutnya adalah build/membangun aplikasi secara cepat. Perancangan pada pembuatan aplikasi masih dalam proses prototype dimana tahap awal dilakukan dengan membuat Object 3D produk pack dan rokok terlebih dahulu dengan bantuan program 3Ds Max dan setelahnya akan diproses untuk pembuatannya toolnya di program Unity [7] [8].

\subsection{Customer Test Drives Mock-Up}

Customer Test Drives Mock-Up (Evaluasi) merupakan tahap dimana pemesan atau instansi melakukan testing pada prototype yang dibuat untuk memperjelas kebutuhan perangkat lunak. Setelah aplikasi selesai dibuat maka selanjutnya aplikasi tersebut akan diuji oleh Customer. Dan pada tahap pengujian itulan nantinya didapatkan kekurangan pada aplikasi ini, apakah sesuai dengan kebutuhan awal Customer atau tidak jika belum sesuai maka Developer akan mengulangi langkah pertama dan selajutnya hinggan sesuai yang diinginkan Customer.

\section{HASIL DAN PEMBAHASAN}

Aplikasi ini dibangun sebagai sarana untuk menampilkan informasi secara detail produk rokok dari pack maupun rokok itu sendiri dalam bentuk Object 3D. Dari jenis produk terbaru hingga produk lama yang masih exsis diproduksi.dimana bentuk 3D akan ditampilkan melalui sebuah maker yang akan memunculkan 3 Object 3D yang berbeda dapat dilihat pada tabel 1. Dengan dibangunnya aplikasi ini diharapkan dapat membantu meminimalisir pengeluaran biaya dari perusahaan dan menambah daya tarik promosi produk pemasaran sekarang ini. Aplikasi yang dibangun menggunakan bhasa C\# dan dengan menggunakan tool Unity dan monodevelope, Android SDK. Sedangakan untuk pembuatan Object 3D menggunkan program 3Ds Max 2010. Selain itu juga aplikasi ini menggunakan library Vuforia sebagai tool untuk membuat aplikasi Augmented Reality. Library Vuforia dapat didownload situs resminya https://Developer.vuforia.com/resources/sdk/Unity yang merupakan situs resmi Qualcom. 
Tabel 1. Maker aplikasi augmented reality ARDjarum

\begin{tabular}{|c|c|c|c|c|c|}
\hline No & Gambar Marker & informasi & No & Gambar Marker & informasi \\
\hline 1 & & 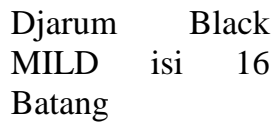 & 5 & & $\begin{array}{l}\text { Djarum LA Merah isi } \\
16 \text { Batang }\end{array}$ \\
\hline 2 & BL CK & $\begin{array}{l}\text { Djarum Black isi } \\
16 \text { Batang }\end{array}$ & 6 & & $\begin{array}{l}\text { Djarum MLD isi } 20 \\
\text { Batang }\end{array}$ \\
\hline 3 & $\frac{\text { CLAVOÜ }}{\text { PREMID }}$ & $\begin{array}{l}\text { Djarum Clavo isi } \\
12 \text { Batang }\end{array}$ & 7 & 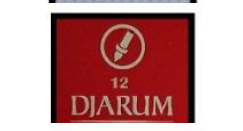 & $\begin{array}{l}\text { Djarum Super } 12 \text { isi } \\
12 \text { Batang }\end{array}$ \\
\hline 4 & & $\begin{array}{l}\text { Djarum LA Ice isi } \\
16 \text { Batang }\end{array}$ & 8 & $\frac{\text { DJARUM }}{\text { SUPER }_{16}}$ & $\begin{array}{l}\text { Djarum Super } 16 \text { isi } \\
16 \text { Batang }\end{array}$ \\
\hline
\end{tabular}

Mekanisme dari proses aplikasi Augmented Reality dapat dijelaskan pada gamabr 1 yaitu dimulai dari marker gambar logo produk rokok Djarum pada katalog. Kemudia katalog tersebut ditampilkan didepan kamera smartphone, dari kamera akan membaca dan aplikasi akan mendeteksi marker tersebut. Pendeteksian marker yang disimpan didalam smartphone menggunakan alogaritma Natural Feature Tracking dari alogaritma dasar fast corner detection yang telah dikembangkan oleh pihak vuforia. Marker akan dideteksi contras beda antar pixel,lebih kontras marker maka akan lebih baik pendeteksiannya. Dengan memberi tanda pada pojok pixel dan setelah itu akan diketahui kualitas marker dengan memberikan rating pada marker tersebut. Jika marker tidak cocok dengan marker yang disimpan pada smartphone maka proses akan diulang terus menerus, dan apabila marker cocok maka aplikasi akan merendering Object 3D dan menampilkannya.

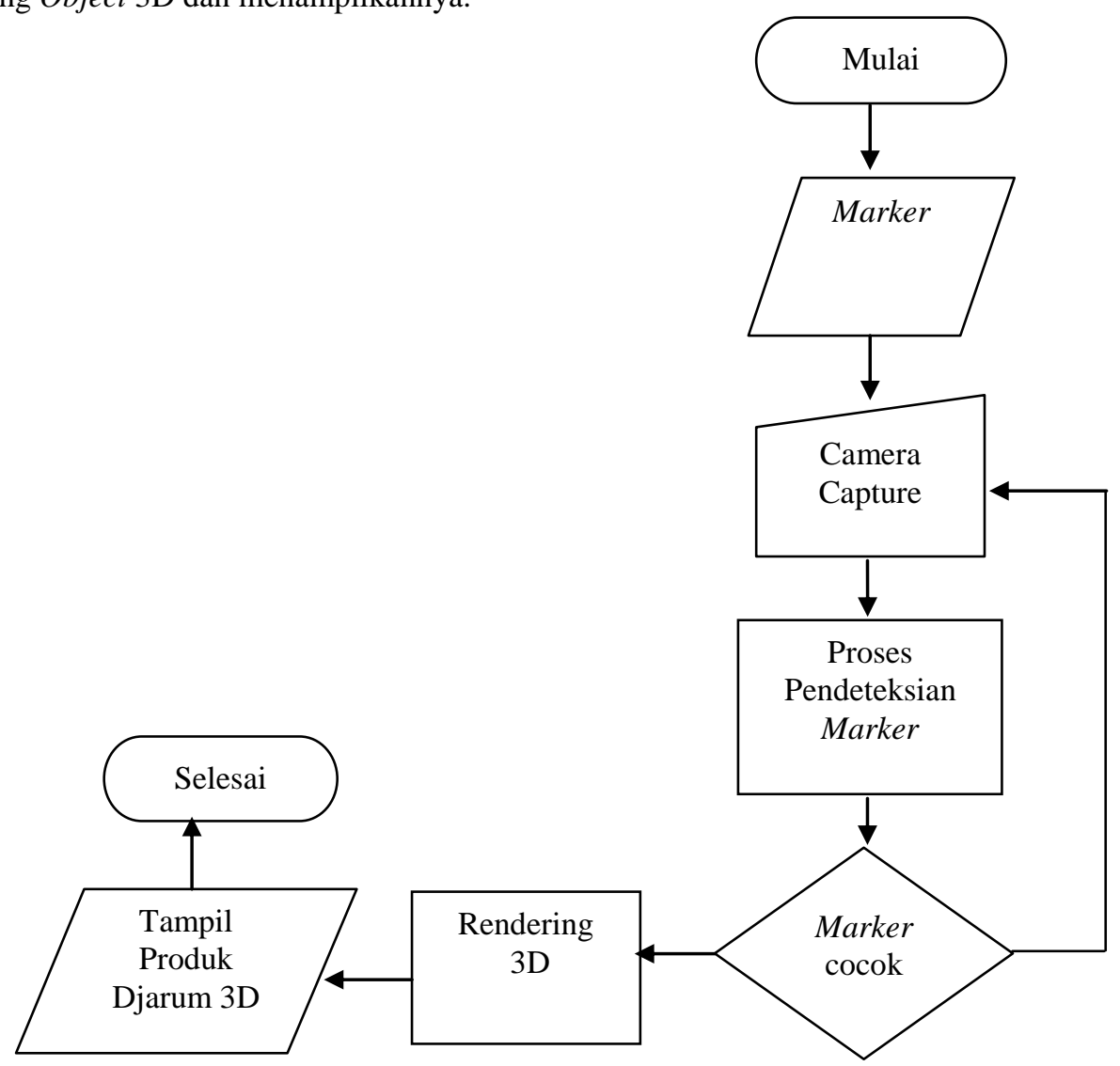

Gambar 1. Mekanisme Aplikasi Augmented Reality 


\section{HASIL APLIKASI}

Pada gambar 2 adalah tampilan dari aplikasi ARDjarum aplikasi Augmented Reality katalog produk rokok Djarum berbasis Android

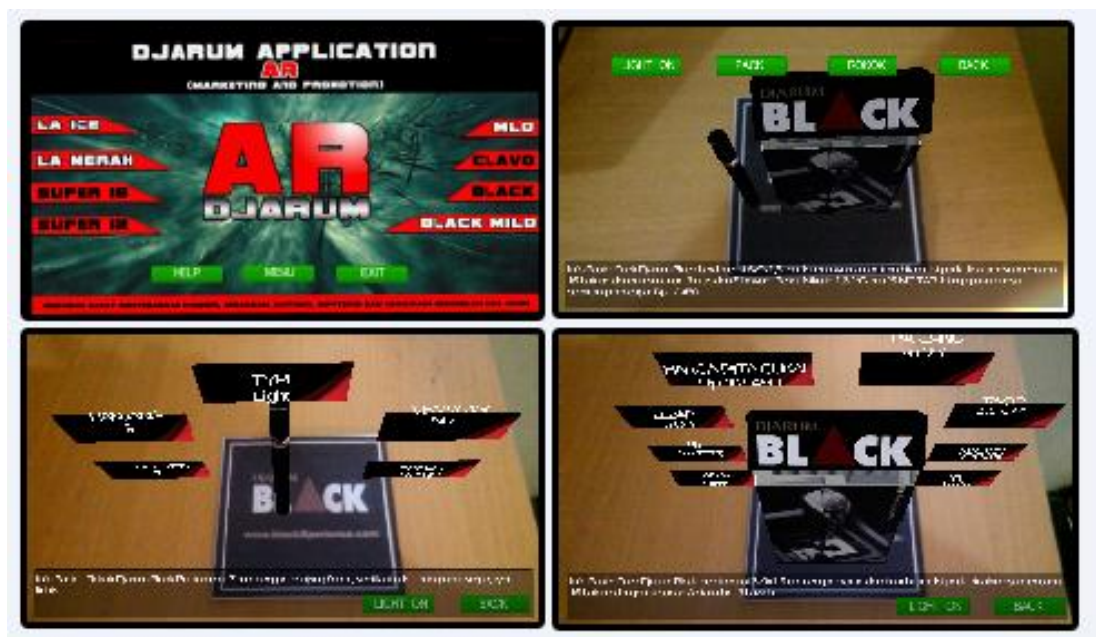

Gambar 2. Aplikasi Augmented Reality ARDjarum

Pada gambar 2 kotak no 1 adalah tampilan splash screen dari aplikasi ARDjarum Home, sedangkan pada kotak no 2 merupakan tampilan menu GO saat pertama kali kamera smartphone mendeteksi marker, untuk kotak no 3 pada gambar 2 menampilkan splash screen dari Object 3D rokok dengan disertai informasi secara mendetail pada tiap produk yang ditampilkan. Terakhir pada kotak no 4 gambar 2 menampilkan splash screen dari Object 3D pack dengan disertai informasi secara detail dari produk tersebut.

\section{PENGUJIAN APLIKASI}

Pengujian aplikasi ini menggunakan teknik pengujian black box. Black box testing adalah pengujian yang dilakukan hanya mengamati hasil eksekusi melalui data uji dan memeriksa fungsional dari perangkat lunak. Jadi dianalogikan seperti kita melihat suatu koatak hitam, kit hanya bisa melihat penampilan luarnya saja, tanpa tau ada apa dibalik bungkus hitam nya. Sama seperti pengujian black box, mengevaluasi hanya dari tampilan luarnya(interface nya), fungsionalitasnya.tanpa mengetahui apa sesungguhnya yang terjadi dalam proses detilnya (hanya mengetahui input dan output). Dimana pada tahap ini akan menguji fungsionalitas pada fitur-fitur yang disediakan oleh aplikasi. Pada tabel 2 adalah hasil dari pengujian fungsionalitas aplikasi, dan dapat disimpulkan bahwa pengujian fungsionalitas ini berjalan sesuai dengan yang diharapkan.

Pengujian berikutnya adalah pengujian Operation Processing aplikasi ARDjarum. Pengujian ini dilakukan karena aplikasi memuat banyak Object 3D, sehingga jika aplikasi ini dijalankan pada device yang berbeda-beda dan dengan spesifikasi dari smartphone yang beberda pula maka, hasil dari respon time juga akan berbeda atau berubah. Pengujian ini hanya dilakukan saat loading kamera smartphone. Dimana proses ini yang akan menentukan perbedaan respon time. Pada pengujian aplikasi ini, akan dilakukan pada 3 device smartphone dengan brand dan spesifikasi yang berbedayaitu dijelaskan pada tabel 3 .

Sedangkan pada tabel 4 merupakan hasil pengujian Operation Processing kamera smartphone. Pada pengujian ini dapat disimpulkan bahwasemakin tinggi spesifikasi dari device maka semakin cepat pula loading time yang terjadi pada aplikasi yang dijalankan.

Pengujian selanjutnya adalah pengujian resolusi layar aplikasi ARDjarum. Pengujian ini dilakukan karena setiap smartphone memiliki ukuran resolusi layar yang berbeda-beda. Pada tabel 5. merupakan hasil dari pengujian resolusi layar aplikasi ARDjarum. Pada pengujian ini dapat disimpulkan bahwa setiap resolusi device yang berbeda maka, akan dihasilkan ukuran yang berbeda pula pada interface aplikasi. Sebagai pada device experia M2 dan device Andromax U2 terjadi perubahan yang signifikan pada tombol dan informasi yang tertulis pada rendering Object 3D pack maupun Rokok. 
Tabel 2. Hasil pengujian fungsionalitas aplikasi ARDjarum

\begin{tabular}{|c|c|c|c|c|}
\hline No & Skenario & Hasil yang diharapkan & Hasil Pengujian & Kesimpulan \\
\hline 1 & Instal APK (Master) & $\begin{array}{l}\text { proses instalasi terpasang dengan } \\
\text { baik di mobile phone android }\end{array}$ & sesuai harapan & valid \\
\hline 2 & $\begin{array}{l}\text { Menjalankan aplikasi } \\
\text { yang terpasang }\end{array}$ & $\begin{array}{l}\text { aplikasi bekerja dengan baik dan } \\
\text { berjalan dengan baik }\end{array}$ & sesuai harapan & valid \\
\hline 3 & $\begin{array}{l}\text { Pendeteksian marker } \\
\text { yang berbeda }\end{array}$ & $\begin{array}{l}\text { object keluar sesuai dengan logo } \\
\text { maker yang telah disediakan }\end{array}$ & sesuai harapan & valid \\
\hline 4 & $\begin{array}{lr}\text { pendeteksian } & \text { maker } \\
\text { yang sama } & \text { utuk } \\
\text { menampilkan } & \text { object } \\
\text { yang berbeda } & \end{array}$ & $\begin{array}{l}\text { object 3D muncul sesuai dengan } \\
\text { maker yang dibuat dan proses } \\
\text { berjalan dengan baik dengan satu } \\
\text { maker dapat load level ke object } \\
\text { lainnya }\end{array}$ & sesuai harapan & valid \\
\hline 5 & $\begin{array}{l}\text { pendeteksian maker } \\
\text { untuk menampilkan } \\
\text { object pack dengan } \\
\text { informasi sesuai dengan } \\
\text { makernya }\end{array}$ & $\begin{array}{l}\text { camera mobile phone dapat } \\
\text { mengcapture dengan baik pada } \\
\text { maker dan object 3D pack dapat } \\
\text { muncul sesuai dengan makernya }\end{array}$ & sesuai harapan & valid \\
\hline 6 & $\begin{array}{lr}\text { pendeteksian maker } \\
\text { untuk menampilkan } \\
\text { object rokok dengan } \\
\text { informasinya sesuai } \\
\text { dengan makernya }\end{array}$ & $\begin{array}{l}\text { camera mobile phone dapat } \\
\text { mengcapture dengan baik pada } \\
\text { maker dan object 3D rokok dapat } \\
\text { muncul sesuai dengan makernya }\end{array}$ & sesuai harapan & valid \\
\hline 7 & $\begin{array}{l}\text { memastikan } \quad \text { tombol } \\
\text { kembali }\end{array}$ & $\begin{array}{l}\text { jika ditekan tombol back maka } \\
\text { tampilan akan kembali pada menu } \\
\text { sebelumnya tanpa ada error }\end{array}$ & sesuai harapan & valid \\
\hline 8 & $\begin{array}{ll}\text { memastikan tombol } & \text { tomt berfungsi }\end{array}$ & $\begin{array}{l}\text { jika ditekan tombol about maka } \\
\text { tampilan akan muncul mengenai } \\
\text { informasi Developer aplikasi } \\
\text { tersebut }\end{array}$ & sesuai harapan & valid \\
\hline 9 & $\begin{array}{l}\text { Memastikan } \\
\text { profil } \\
\text { berfungsi }\end{array}$ & $\begin{array}{l}\text { jika ditekan tombol about maka } \\
\text { tampilan akan muncul mengenai } \\
\text { informasi profil dari PT Djarum } \\
\text { secara singkat aplikasi tersebut }\end{array}$ & sesuai harapan & valid \\
\hline 10 & $\begin{array}{l}\text { memastikan tombol help } \\
\text { berfungsi }\end{array}$ & $\begin{array}{l}\text { jika ditekan tombol about maka } \\
\text { tampilan akan muncul mengenai } \\
\text { informasicara penggunaan aplikasi } \\
\text { ARDjarum tersebut }\end{array}$ & sesuai harapan & valid \\
\hline 11 & $\begin{array}{l}\text { meletakkan } \\
\text { didekat kamera } \\
\text { phobile } \\
\text { phondroid }\end{array}$ & $\begin{array}{l}\text { maker terlihat dengan jelas dan } \\
\text { pendeteksian maker dapat } \\
\text { memunculkan object } 3 \mathrm{D} \text { dengan } \\
\text { baik }\end{array}$ & sesuai harapan & valid \\
\hline
\end{tabular}

Tabel 3. Device pengujian aplikasi

\begin{tabular}{ccccc}
\hline No & Spesifikasi & Experia M2 & Andromax U2 & Lenovo A369i \\
\hline 1 & Ram & $1 \mathrm{~Gb}$ & $1 \mathrm{~Gb}$ & $512 \mathrm{Mb}$ \\
2 & Os Android & V4.4.2 (Kit Kat) & V4.1.2 (Jellybean) & V4.2.2 (Jellybean) \\
& & Quad Core 1.2 Ghz & Quad Core 1.2 Ghz & Dual Core 1.3 Ghz \\
3 & CPU & Cortex-A7 & Cortex-A7 \\
& & Qualcomm MSM8226- & Qualcom snapdragon & Mediatek MT6572 \\
4 & Chipset & 0 Snapdragon 400 & MSM8625Q & Mali-400 \\
5 & GPU & Adreno 305 & Adreno 203 & 2Mp \\
6 & Camera & $8 \mathrm{Mp}$ & $8 \mathrm{Mp}$ & \\
\hline
\end{tabular}




\section{Tabel 4. Hasil pengujian operation processing aplikasi ARDjarum}

\begin{tabular}{|c|c|c|c|c|}
\hline No & Operation Processing & Experia M2 & Andromax U2 & Lenovo A369i \\
\hline 1 & Loading Awal aplikasi & lancar & lancar & agak lambat \\
\hline 2 & Resolusi tampilan aplikasi & $\begin{array}{c}\text { tampilan } \\
\text { aplikasi lebih } \\
\text { sempit }\end{array}$ & $\begin{array}{l}\text { tampilan aplikasi } \\
\text { sesuai }\end{array}$ & $\begin{array}{l}\text { tampilan aplikasi } \\
\text { terlalu besar }\end{array}$ \\
\hline 3 & Proses Pendeteksian maker & lancar & lancar & lambat \\
\hline 4 & Proses saat rendering menu GO & lancar & agak lambat & lambat \\
\hline 5 & $\begin{array}{l}\text { Proses rendering Object 3D } \\
\text { pack }\end{array}$ & lancar dan halus & $\begin{array}{c}\text { agak lancar tapi } \\
\text { halus }\end{array}$ & $\begin{array}{c}\text { lambat dan terbata- } \\
\text { bata }\end{array}$ \\
\hline 6 & $\begin{array}{c}\text { Proses rendering Object 3D } \\
\text { rokok }\end{array}$ & lancar dan halus & $\begin{array}{l}\text { agak lancar tapi } \\
\text { halus }\end{array}$ & $\begin{array}{l}\text { lambat dan terbata- } \\
\text { bata }\end{array}$ \\
\hline 7 & $\begin{array}{l}\text { Loading saat proses kembali } \\
\text { kemenu sebelumnya }\end{array}$ & lancar & lancar & lambat \\
\hline
\end{tabular}

Tabel 5. Hasil pengujian resolusi layar aplikasi ARDjarum

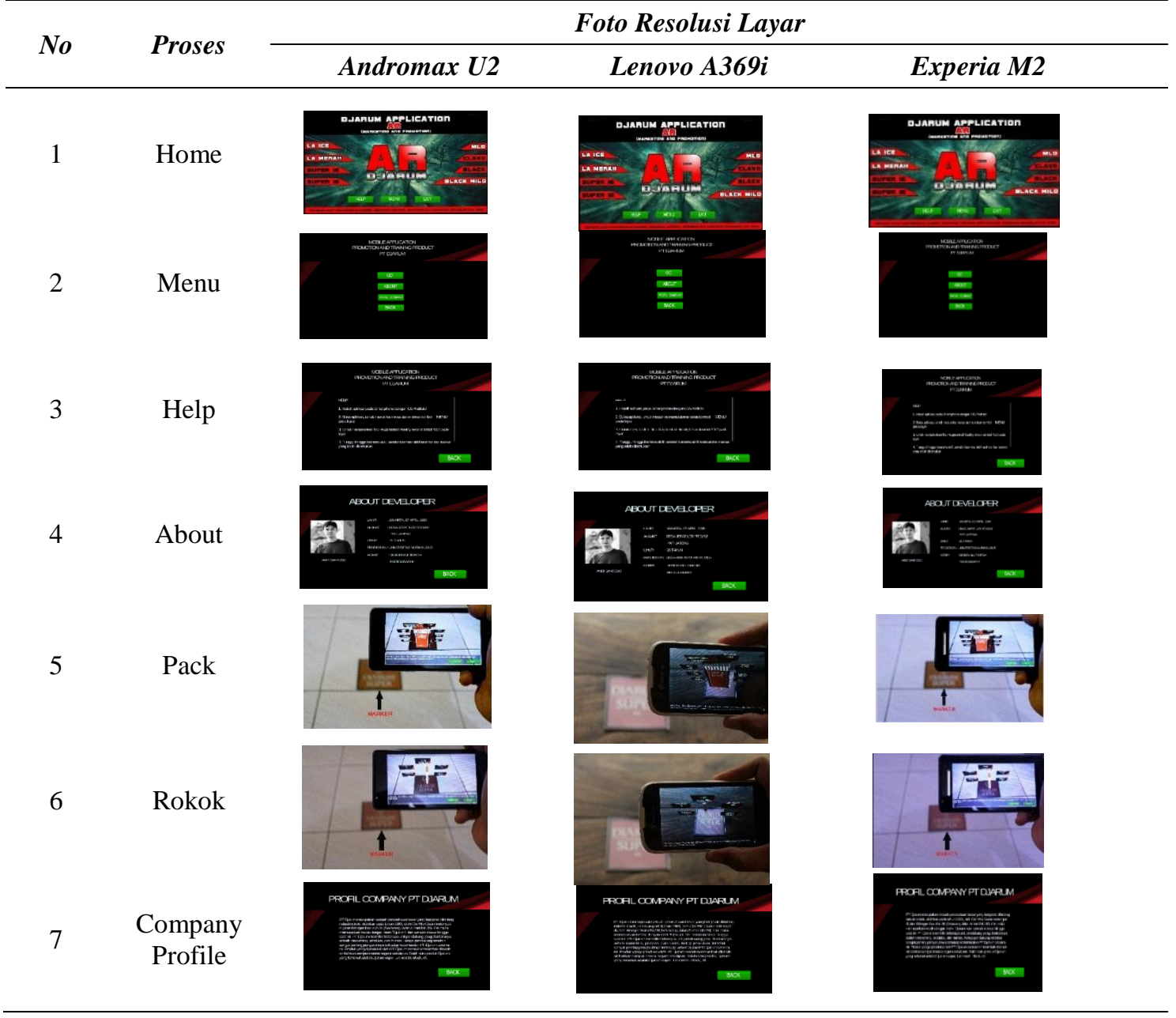




\section{KESIMPULAN}

Berdasarkan analisa dan pengujian pada pada penelitian aplikasi ARDjarum maka dapat diambil kesimpulan sebagai berikut:

1) Pendeteksian maker berjalan dengan baik dan dapat memunculkan tiga Object dalam satu maker.

2) Pemanfaatan tegnologi Augmented Reality pada aplikasi ini berjalan dengan baik dan sesuai dengan perancangan sebelumnya,yaitu menggabungkan anatara Object 3D dengan lingkungaan nyata

3) Interaksi menggunakan tombol yang disediakan pada aplikasi ini memudahkan pengguna untuk mengetahui detail dari produk PT Djarum dari produk lama maupun produk baru.

4) Dalam pendeteksian pola maker, perlu diperhatikan detail dan kualitas maker yang di capture oleh camera mobile phone.

\section{DAFTAR PUSTAKA}

[1] Fernando, Membuat Aplikasi Android Augmented Reality Menggunakan Vuforia SDK dan Unity, Manado: Buku AR Online, 2013.

[2] T. L. Muhammad Rifa'i, "PENERAPAN TEKNOLOGI AUGMENTED REALITY PADA APLIKASI KATALOG RUMAH BERBASIS ANDROID," dalam Prosiding SNATIF, Kudus, 2014.

[3] T. Listyorini, "3d-Catalog Mountain View Residence Berbasis Augmented Reality," dalam Prosiding SAINTIKS, Bandung, 2014.

[4] Anonim, Buku Latihan Mendesain Object 3 Dimensi dengan 3D Studio Max 8, Jakarta: PT Elex Media Komputindo, 2006.

[5] I. Setiawanto, "Penerapan Augmented Reality pada kotak ponsel sebagai media periklanan virtual," Jurusan Tekhnik Informatika,AMIKOM, Yogyakarta, 2012.

[6] A.-B. Ladjamuddin, Analisa dan Desain Sistem Informasi, Tangerang: Graha Ilmu, 2005.

[7] Andi, Autodesk 3Ds max 2011 Untuk pemula, Yogyakarta: Andi Offset, 2011.

[8] Andi, Adobe Photoshop CS5 untuk manipulasi photo profesional, Semarang: Wahana Komputer, 2011. 